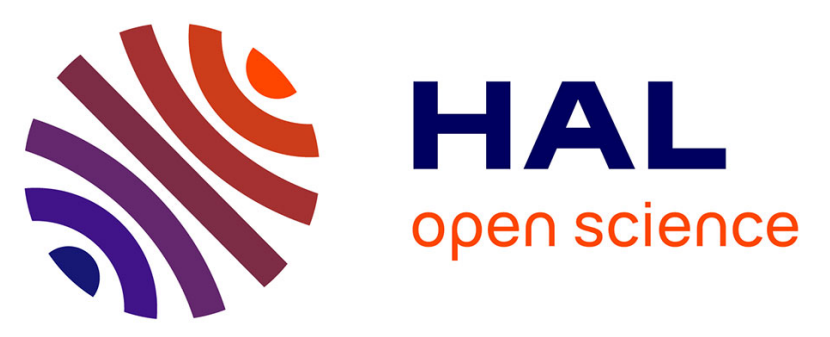

\title{
Hydrogeophysical Characterization in a Volcanic Context From Local to Regional Scales Combining Airborne Electromagnetism and Magnetism
}

Marc Dumont, Pierre-Alexandre A Reninger, Bertrand Aunay, Alexandre Pryet, Damien Jougnot, Jean-Lambert L Join, Laurent Michon, Guillaume Martelet

\section{To cite this version:}

Marc Dumont, Pierre-Alexandre A Reninger, Bertrand Aunay, Alexandre Pryet, Damien Jougnot, et al.. Hydrogeophysical Characterization in a Volcanic Context From Local to Regional Scales Combining Airborne Electromagnetism and Magnetism. Geophysical Research Letters, 2021, 48 (12), pp.e2020GL092000. 10.1029/2020gl092000 . hal-03266446

\section{HAL Id: hal-03266446 https://hal.science/hal-03266446}

Submitted on 21 Jun 2021

HAL is a multi-disciplinary open access archive for the deposit and dissemination of scientific research documents, whether they are published or not. The documents may come from teaching and research institutions in France or abroad, or from public or private research centers.
L'archive ouverte pluridisciplinaire HAL, est destinée au dépôt et à la diffusion de documents scientifiques de niveau recherche, publiés ou non, émanant des établissements d'enseignement et de recherche français ou étrangers, des laboratoires publics ou privés. 


\section{Geophysical Research Letters}

\author{
RESEARCH LETTER \\ 10.1029/2020GL092000 \\ Key Points: \\ - Magnetic measurements help \\ constrain the hydrological \\ interpretation of resistivity models \\ in volcanic settings \\ - Hydrogeophysical interpretations \\ of deep airborne electromagnetic \\ imaging unveil groundwater \\ stratified flows between volcanic \\ units \\ - Coupled analysis of airborne \\ electromagnetic and magnetic \\ data sets allows us to improve \\ groundwater management from \\ local to regional scale
}

Supporting Information: Supporting Information may be found in the online version of this article.

Correspondence to:

M. Dumont,

dumont.mrc@gmail.com

Citation:

Dumont, M., Reninger, P. A., Aunay, B., Pryet, A., Jougnot, D., Join, J. L., et al. (2021). Hydrogeophysical characterization in a volcanic context from local to regional scales combining airborne electromagnetism and magnetism. Geophysical Research Letters, 48, e2020GL092000. https://doi. org/10.1029/2020GL092000

Received 9 DEC 2020

Accepted 18 MAY 2021

(C) 2021. American Geophysical Union. All Rights Reserved.

\section{Hydrogeophysical Characterization in a Volcanic Context From Local to Regional Scales Combining Airborne Electromagnetism and Magnetism}

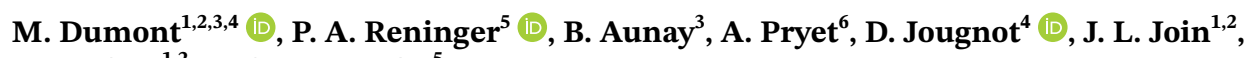 \\ L. Michon ${ }^{1,2}$, and G. Martelet ${ }^{5}$ \\ ${ }^{1}$ Université de La Réunion, Laboratoire GéoSciences Réunion, Saint-Denis, France, ${ }^{2}$ Université de Paris, Institut de \\ Physique du Globe de Paris, CNRS, UMR 7154, Paris, France, ${ }^{3}$ BRGM, Saint-Denis, France, ${ }^{4}$ Sorbonne Université, \\ CNRS, EPHE, UMR 7619 METIS, Paris, France, ${ }^{5}$ BRGM, Orléans, France, ${ }^{6}$ EA 4592 Géoressources et Environnement, \\ Bordeaux INP and Université Bordeaux Montaigne, Pessac, France
}

\begin{abstract}
In volcanic islands, a crucial step in managing watershed water resources is the characterization of groundwater aquifers from local to regional scales. Airborne geophysical data provide high-resolution images down to hundreds of meters below the surface, over large areas. Yet, the production of an accurate interpretation of regional geophysical imagery may be time consuming or limited by the low density of geological and hydrological field observations. Here, we propose an approach combining airborne electromagnetic and magnetic data in order to reduce geophysical ambiguities and provide a multiscale hydrogeophysical characterization of Piton des Neiges volcano (Réunion Island). With limited calibration data, this methodology produces a geological model more accurate than using airborne electromagnetic data alone. Through the continuous coverage of both methods, we demonstrate the influence of volcanic unit geometries on groundwater flows within the critical zone and we highlight major structures impacting groundwater flows at both local and regional scales.
\end{abstract}

Plain Language Summary Groundwater characterization from local to regional scale is an essential element especially for sustainable water policy. In volcanic settings, the complexity of the subsurface and geological structures is still poorly integrated into hydrological models, leading to uncertainties in predictive models. Our study aims to combine two geophysical methods acquired during airborne surveys over Réunion Island in order to (a) improve the accuracy of airborne geophysical image interpretation without limited external information, (b) characterize structures and their influences on groundwater flows, and (c) upscale these results from local to regional scales. The methodology may be applied to other complex geological settings in order to integrate local and regional heterogeneities into hydrological models.

\section{Introduction}

In volcanic islands, understanding the distribution of groundwater reservoirs as well as their dynamics and connection at the island scale is critical for drinking water autonomy. The first hydrogeological studies on the Canary and Hawaiian Islands have described the regional groundwater functioning of volcanic islands by dividing the territory into two sectors: coastal and inland areas (Custodio et al., 1988; Peterson, 1972). While groundwater aquifers are clearly identified and reachable in coastal areas (Gingerich \& Voss, 2005; Herrera \& Custodio, 2014), the thickness of unsaturated stacks of lava flows can reach up to thousands of meters in the central parts of volcanoes. Within this thick vadose zone, groundwater flows are controlled by complex geological structures due to polygenetic volcanic activity (Izquierdo, 2014; Vittecoq et al., 2014) and the evolution of hydrodynamic properties of volcanic rocks induced by weathering and alteration processes (Custodio, 2004; Join et al., 2005; Lachassagne et al., 2014). The groundwater flows are distributed among three different aquifer categories based on the afore mentioned geological parameters: shallow aquifers, perched aquifers, and basal aquifers (Join et al., 2016). Owing to the thickness of the vadose zone, these circulations as well as inland aquifer geometries remain unclear, thereby increasing the complexity of groundwater access inland. Groundwater extraction is concentrated on the coastal edge ( $82 \%$ in Reunion Island; Join et al., 2005), where aquifers 
are vulnerable to saltwater intrusion (Oki et al., 1998; Pryet et al., 2012). In order to improve regional groundwater management, it is mandatory to improve the characterization of inland aquifers and include their possible impact on the recharge rates of basal aquifers. To this end, the vadose zone needs to be studied on both local and regional scales so as to define the aquifer geometries and groundwater watersheds (Vittecoq et al., 2019).

Over the past few decades, near-surface geophysics applied to environmental issues has paved new ways for characterizing geological and hydrological contrasts from local to regional scales (Binley et al., 2015; Parsekian et al., 2015). One of the main objectives of hydrogeophysics is to provide reliable and meaningful images of the subsurface with the best spatial resolution. However, since it is essential to integrate local heterogeneities into larger groundwater behaviors, mapping groundwater pathways at a watershed level and on a regional scale remains challenging. In order to address this issue, we use airborne time domain electromagnetic (TDEM) and total magnetic field data (Sørensen \& Auken, 2004) to image the subsurface electrical resistivity and magnetic properties at a regional scale, up to several thousands of kilometers of flight lines (Chandra et al., 2019; Ley-Cooper et al., 2019). Airborne electromagnetics (AEM) is an efficient method for tackling several groundwater issues as it is sensitive to lithological contrasts, clay content, groundwater saturation, and salinity (Ball, Bedrosian, et al., 2020; Dumont et al., 2018; Foged et al., 2014; Minsley et al., 2012). Nevertheless, this method has significant limitations, especially in complex settings, because of the ambiguity in the interpretation of the resistivity values imaged. Previous studies imaged different types of formation, saturation, or alteration degrees with the same range of resistivity. As an example, while d'Ozouville et al. (2008) interpreted 50-200 $\Omega \cdot \mathrm{m}$ as saturated basaltic flows in Santa Cruz Island (Galapagos), Pryet et al. (2012), in San Cristobal Island, separated this threshold into two categories with either saturated $(30-100 \Omega \cdot \mathrm{m})$ or weathered formations $(100-400 \Omega \cdot \mathrm{m})$. These results show the need for a combined interpretation of resistivity data with geological, geophysical, and/ or groundwater measurements or observations. On the other hand, airborne acquisition significantly increases the number of data and the coverage of the geophysical surveys, thereby adding complexity to the analysis.

Previous studies showed how the combination of electromagnetic and magnetic measurements could improve the imaging of shallow hydrothermal alteration and ground water by using the magnetic data to differentiate low resistivities related to hydrothermal alteration from highly mineralized groundwater (Dumont et al., 2019; Finn et al., 2007; Finn et al., 2018; Peterson et al., 2021). Here, we combine both AEM and magnetic data to (a) unravel issues of resistivity ambiguity, (b) recover a geological model of the critical zone in volcanic settings, and (c) improve our understanding of large-scale groundwater flows within the vadose zone through the different types of aquifer over a greater area and different volcanic environment than previous work. In order to achieve a consistent method across scales, our approach is focused on the optimal use of both electromagnetic and magnetic airborne geophysical data sets combined with petrophysical analysis of resistivity variations as well as geological and groundwater knowledge from previous studies. The objective is to define the most robust and precise geological structures and induced groundwater flows across scales assuming local scale uncertainties in the definition of the geometries and behavior. Our approach does not aim to replace high-resolution multidisciplinary studies for characterizing and quantifying local water resources.

Here, we apply an approach from Réunion Island (Indian Ocean) that has been used to characterize the stratification of groundwater flows within the northeastern slope of Piton des Neiges volcano. The resistivity model informs us of lithological, saturation, and weathering contrasts below the surface, down to $500 \mathrm{~m}$. Magnetic measurements provide integrated information on geological structures and can differentiate lava flows, especially if the stratigraphy contains normal and reversely magnetized flows (Gailler \& Lénat, 2012). AEM provides an accurate 3D imagery of lithological units, while the extension of volcanic units is defined with magnetic maps. The combined analysis of both geophysical imaging mitigates the limitations in interpreting resistivity and magnetic measurements in complex geological contexts. Since local studies unravel magnetic patterns in buried valleys, they can be upscaled to delineate major hydrogeological structures over the entire Piton des Neiges volcano, highlighting the presence of large-scale volcanic structures. In addition, these remote methods are the only way to obtain hydrologic data for the rugged, heavily vegetated volcano (see supporting information S1). 


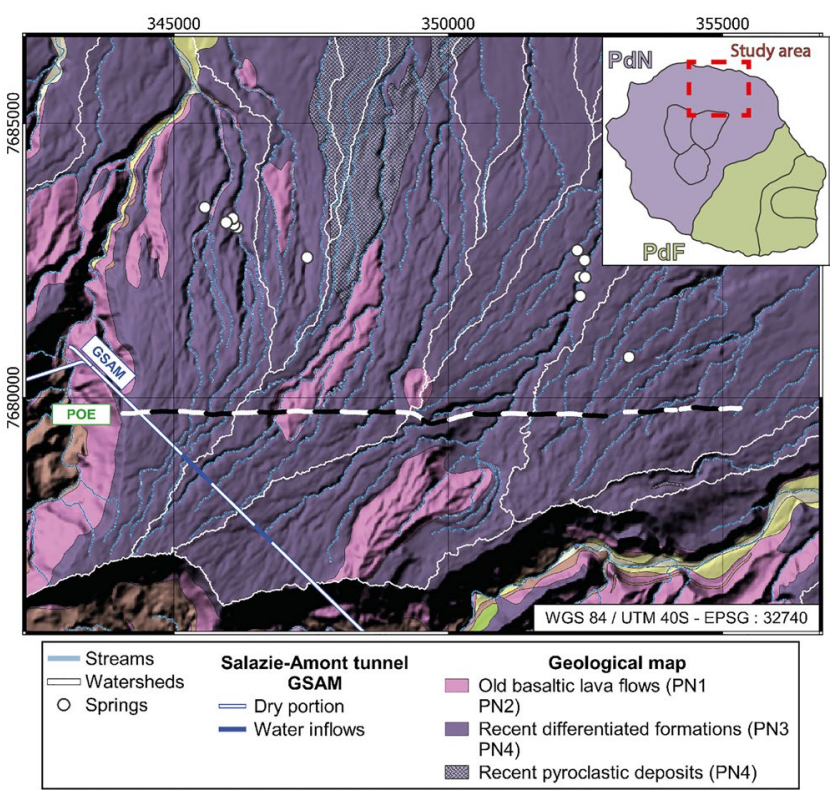

Figure 1. Geological map of Plaine des Fougères, part of the northern flank of Piton des Neiges (modified from Billard, 1974). The inset represents Réunion Island with Piton des Neiges (PdN) and Piton de la Fournaise (PdF) volcanoes. The POE line indicates the AEM profile shown in Figure 2.

\section{Study Area and Methods}

Réunion Island is a volcanic island located in the western part of the Indian Ocean (Figure 1). Our study focuses on the Piton des Neiges volcano resulting from the accumulation of basaltic and trachybasaltic flows (Salvany et al., 2012) during the last two magnetic periods-the reversed Matuyama chron (2.581-0.78 Myr) and normal Brunhes chron (0.780 Myr; Lénat et al., 2001). The emerging volcanic period, called La Montagne (LM), occurred between 3 and 1.8 Myr and produced basaltic rocks.

The two subsequent eruptive periods, PN1 (1.4-0.95 Myr) and PN2 (0.6-0.43 Myr), built successive edifices made of basaltic lava flows. After a lull of $90 \mathrm{kyr}$, differentiated magmas led to the construction of PN3 (340-180 kyr) and PN4 (140-29 kyr; Salvany et al., 2012). The five eruptive periods were separated by lulls characterized by both weathering and destructive processes (Gayer et al., 2019). In Réunion Island, magnetic anomalies are mainly controlled by thermoremanent magnetization (Gailler \& Lénat, 2012). Basaltic rocks are characterized by a high magnetic intensity and a magnetic polarity and orientation inherited from the geomagnetic field at their age of emergence (average Koenigsberger ratio is above 7; Chauvin et al., 1991). These characteristics do not vary with time and weathering processes can decrease magnetic intensity (Gailler \& Lénat, 2012). Thus, inverse magnetization refers to LM and PN1 formations, whereas normal magnetization relates to PN2 to PN4 units.

The volcano's history, including alternating constructive and destructive periods, results in a complex imbricated structure (Salvany et al., 2012).

To understand the volcanic stratigraphy (i.e., lava flows from the same eruptive period), we first focus on the northeastern slope of the volcano, Plaine des Fougères $\left(90 \mathrm{~km}^{2}\right)$, extending from 200 to 1,800 $\mathrm{m}$ above sea level (Figure 1). The substratum of the area includes the oldest LM and PN1 formations with outcrops in the southern part of the area and steep ravines. Outcrops of these formations are also visible in a deeply drilled tunnel called Salazie-amont (GSAM), which crosscuts the study area 1,000 m below the surface and intersects three aquifer sectors (Figure 1; Maréchal et al., 2014). The slope consists of homogeneous pyroclastic units emplaced during PN4 overlapping with differentiated PN3 lava flows. The study area, located more than $10 \mathrm{~km}$ away from the volcano center, is too distant to be influenced by active hydrothermal processes (Bénard et al., 2019). All volcanic products resulting from the same eruptive period form a volcanic unit comprising a stack of lava flows and pyroclastic interflows. In La Réunion, Join et al. (2005) demonstrated that lava flows are composed of $80 \%$ of massive lava and $20 \%$ of scoriaceous/brecciated interflow pyroclasts. From a hydrodynamic point of view, interflows are transmissive and capacitive porous horizons, whereas massive lava flows are considered to be transmissive due to cooling fracturing but with lower capacitive properties. The stacking of lava flows induces hydrodynamic anisotropy with higher horizontal permeability. Between the eruptive periods, outcropping formations are exposed to weathering and erosion processes, which creates weathering profiles from the top to the bottom of every volcanic unit (Gayer et al., 2019). Such processes first impact brecciated interflows, while massive lava flows are more resistant to weathering processes (Eggleton et al., 1987). Finally, since rainfall and soil biological activity are important drivers of weathering, the degree of weathering decreases with depth.

A SkyTEM survey was conducted over the entire island (more than 2,500 km²; Figure 1; Martelet et al., 2014). AEM data were acquired at $30 \mathrm{~m}$ intervals along flight lines with a low moment to ensure near-surface resolution and a high moment to increase the depth of investigation (Sørensen \& Auken, 2004). During the high moment off-times, the magnetic field was measured providing the same lateral resolution. On the regional scale, the electromagnetic data set was processed with a standard processing scheme developed by HGGC (Auken et al., 2009). Over the Plaine des Fougères area, a specific scheme was applied to improve AEM data density and resolution (Reninger et al., 2019). Both AEM inversions were achieved using a quasi-3D spatially constrained algorithm (Viezzoli et al., 2008). AEM inverted smooth models at regional and local scales discretize the subsurface in 25-30 layers respectively. The layer thickness of both models 
increases logarithmically with depth, from 5 or $2 \mathrm{~m}$ thick for the first one up to a depth of 350 or $500 \mathrm{~m}$. Magnetic data were processed according to the industry standards, with diurnal removals and IGRF (International Geomagnetic Reference Field) correction, resulting in a residual magnetic field. Reduction to pole (RTP) was then performed to move anomalies over their sources and the X-Y shift of magnetic anomalies created by the geomagnetic field inclination (Baranov, 1957). However, no corrections were applied to decrease topographic impact on the magnetic measurements. Magnetic maps were produced using Geosoft software.

While well data often constrain resistivity models (e.g., Ball, Davis, et al., 2020; Reninger et al., 2016), no near-surface drill holes exist and the great spatial variability of lithology and groundwater processes on volcanoes would not be perceived from scarce drill holes. In order to take such complexity into account, we experiment with an approach based on the definition of geo-electrical features. The latter are defined based on resistivity contrast geometries instead of resistivity values. Each feature, possibly composed of resistive and conductive layers, could be considered as consistent units according to the volcanic stratigraphy of the Piton des Neiges. Resistivity variations within these units will be discussed considering weathering and saturation processes.

\section{Multimethod Airborne Geophysical Interpretations}

We present the 2D magnetic and resistivity section named "POE" (Figures 2a and 2b), where all magnetic anomalies and geo-electrical features observed on the slope-labeled A-E-are imaged. The same analysis was carried out on 35 profiles (along $275 \mathrm{~km}$ of flight lines) in order to delineate spatial geometries and the extent of the five geo-electrical features, as well as the consistency with related magnetic variations (four different 2D resistivity profiles are presented in supporting information S3). On the POE profile, a thin resistive layer $(\approx 500-800 \Omega \cdot \mathrm{m})$ mantles the surface $(\mathrm{E})$. Below, features A and C consist of a 50 to $200 \mathrm{~m}$ thick conductive layer $(<100 \Omega \cdot \mathrm{m})$ overlaying a resistive body $(>1,000 \Omega \cdot \mathrm{m})$. For both features, the resistive and conductive layers show the same geometry with a wide base at the depth and oblique vertical limits. The feature B corresponds to a large resistive body $(800-1,500 \Omega \cdot \mathrm{m})$ in the center of the profile whose oblique limits converge in depth. The feature D consists of U-shaped resistive layers $(500-1,000 \Omega \cdot \mathrm{m})$ covered by a thin conductive horizon $(\approx 100-200 \Omega \cdot \mathrm{m})$. The geometries of the five features are consistent with superimposed units of different eruptive periods. According to their organization, feature A and C should correspond to old altered lava flow lithologies and features B and D are more recent formations covering them. Finally, feature E corresponds to a recent volcanic formation structure.

Each of the five features is therefore characterized by a resistive horizon overlayed by a relatively conductive layer. As their geometries are consistent, both conductive and resistive layers could be gathered in volcanic units composed of a coherent lithology in terms of age. The location of conductive layers at the top of volcanic units and the gradual increase in resistivity from the top to the bottom of volcanic units is consistent with the usual weathering profiles geometry in siliceous settings (Navarre-Sitchler \& Brantley, 2007). In order to attribute resistivity variations to geological or hydrogeological processes, an analysis of sensitivity is provided in the supporting information S2 using the petrophysical model of Waxman and Smits (1968) with basaltic volcano characteristics. According to the petrophysical equation, in coherent geological units, the resistivity is controlled by the saturation and the clay content (taking into account the surface conductivity through the cation exchange capacity). Our petrophysical modeling demonstrates that resistivity variation within volcanic units may be explained either by saturation and/or clay accumulation (cf., supporting information S2). These results clearly show the limitation of resistivity imaging in distinguishing saturation and clay content alone. As it stands, we cannot distinguish whether the conductors are related to saturation, weathering, or both processes. In addition, older volcanic units at depth have lower overall resistivities than shallower units. This result is consistent with the findings from the study of Join et al. (2005), which shows a progressive decrease in the resistivity of volcanic units as a function of their depth and thus their age. This evolution is attributed to a progressive alteration of the formations inducing a decrease in their hydrodynamic properties (Join et al., 2005).

We differentiate volcanic units derived from the resistivity imaging with magnetic polarity variation in order to (a) confirm the lithological analysis from the resistivity model and (b) estimate the relative age of 

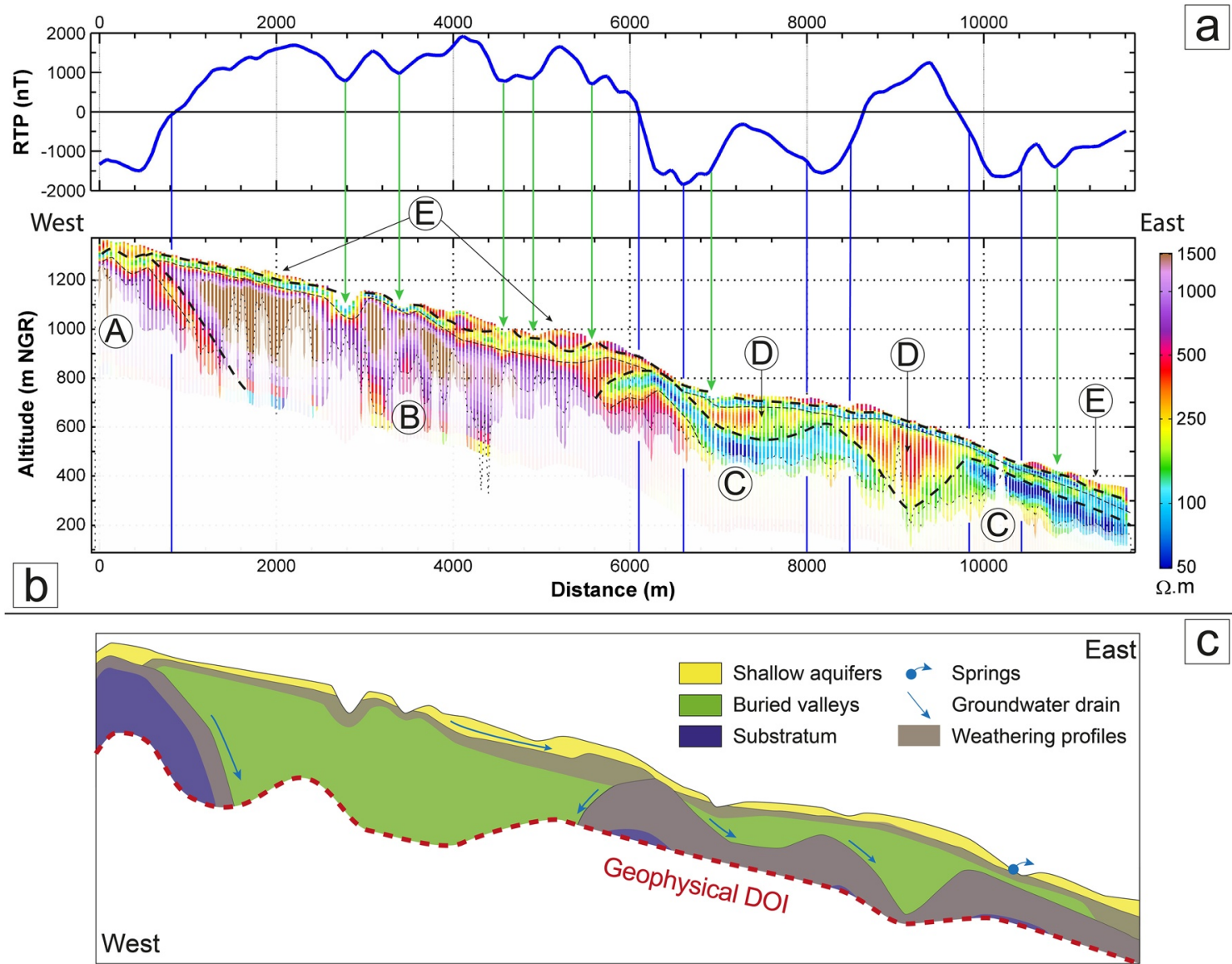

Figure 2. (a) POE, (b) reduced to the pole magnetic signal, and resistivity profiles, crossing the Plaine des Fougères area from west to east. Five features (a-e) are identified in the resistivity profile, separated by black dashed lines. Blue lines highlight the magnetic anomaly limits. Green arrows show locations where the RTP signal is affected by the lack of PN4 formations, in ravines. (c) Conceptual groundwater model based on hydrogeophysical interpretations. Shallow aquifers result from later volcanic products from pyroclastic units of the end of PN3 and PN4 eruptive periods. Buried valleys are filled with PN2 and PN3 lava flows. The substratum is characterized by old weathered lava flows from LM and/or PN1 eruptive periods.

the lithological units imaged. The POE profile can be divided into three major parts: two magnetic lows at the edge of the profile corresponding to old LM and PN1 units, and a magnetic high in the center related to young formations PN2 to PN4. The lateral extension of these structures is consistent with geo-electrical feature extensions (Figure 2a). On a smaller scale, the magnetic anomaly amplitude increases where feature $\mathrm{D}$ becomes thicker, and decreases where $\mathrm{E}$ is eroded (see green arrows in Figure 2a). Features $\mathrm{A}$ and $\mathrm{C}$ are associated with a magnetic low $(\approx-1,500 \mathrm{nT})$ corresponding to old volcanic units (LM and/or PN1). In both cases, the magnetic response is substantially identical, while feature A is characterized by a thin weathered horizon and $\mathrm{C}$ is mainly composed of a thicker conductive layer reflecting thicker weathered zones. This demonstrates the predominance of polarity inversion over the magnetic intensity decrease produced by the weathering of volcanic rocks. Indeed, the alteration first occurs in the scoriaceous horizons, which represent only $20 \%$ of the volume of volcanic units. Thus, a weathering paleo-profile can be characterized by highly weathered interflows between mostly fresh lava flows, which thus preserve their magnetic signature. Filling the old morphology, features B and D reflect two major buried paleo-valleys filled with younger magnetic lava, likely PN2 and PN3, reflected by magnetic highs. During these two phases, the volcano was active with a short period of inactivity that did not allow for the establishment of a significant alteration profile. In depth, the AEM resolution decreases, thereby preventing the imaging of a potentially fine weathered horizon that separates PN2 and PN3 units. The shallow part of the slope mainly consists of a thin resistive layer (E), which increases locally the major magnetic anomaly created by B feature (with a maximum intensity of approximately 1,000 $\mathrm{nT}$ where the layer is the thickest). Its geophysical characteristics and its geometry are consistent with outcropping PN4 formations that appear clearly at the outcrop (Figure 1). 


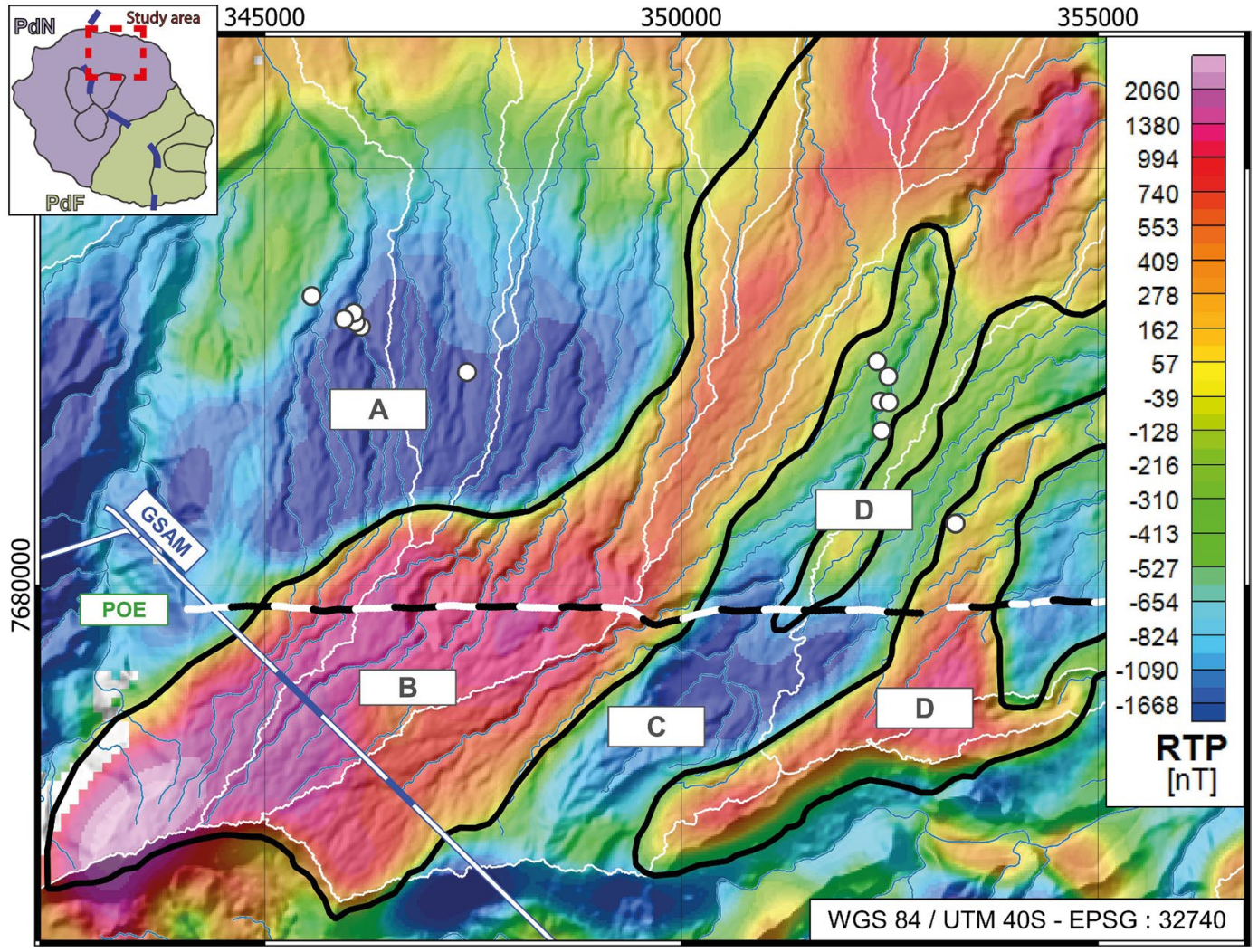

Figure 3. Mapping of two large paleo-valleys eroded between PN1 and PN2 periods using a magnetic map (reduced to the pole). The 2D POE profile is indicated in black and white, changing colors every $500 \mathrm{~m}$ to ease the comparison with Figure 2. The deeply drilled GSAM tunnel is indicated in white, with blue parts corresponding to groundwater outflows. Watersheds of the slope are represented by white lines. The inset represents Réunion Island with both volcanoesPiton des Neiges (PdN) and Piton de la Fournaise (PdF).

The following step consists of comparing the main geological structures derived from airborne geophysical data and hydrogeological data in order to understand water flow behaviors within the critical zone. Previous studies analyzed several springs at the bottom of the Plaine des Fougères volcano slope demonstrating the presence of limited shallow aquifers, emerging at the boundary between recent formations and underlaying older ones (Aunay et al., 2012). The shallower part of the slope is composed of a thin resistive layer (feature E) overlaying the paleo-profile of older units. In Figures S3d and S3e profiles show that springs are located where erosive structures intersect the boundary between PN4 formations and older formations. These elements converge to affirm that the aquifer is present in unaltered resistive formations lying beneath older weathered formations where the increase in clay content, as well as the saturation of these less permeable formations, decreases the resistivity. The resolution of airborne geophysics does not allow for a precise definition of the boundary between saturated and weathered horizons. Nevertheless, as the decrease in resistivity is induced by an increase of clay content, conductive layers could be considered as less permeable. Thus, groundwater flows should occur at the bottom of resistive features as well as at the top of conductive ones. This demonstrates the impact of volcanic unit boundaries, which create lateral pathways at the limit between young formations overlaying old weathered ones. Thus, springs could emerge when these geological boundaries are intersected by the hydrologic network in the slope/flow direction. These results suggest that paleo-weathering profiles drain groundwater flows, creating aquifers at the bottom of volcanic units (Figure 2c).

Previous hydrogeological studies in the deep tunnel demonstrated that water inflows are observed where the tunnel goes through PN2/3 recent formations, below magnetic feature B (Figure 3). An analytical solution has been used to model groundwater inflows within the tunnel during the drilling (Maréchal et al. 2014). Model-calibrated permeability of old LM/PN1 formations ranges from $10^{-7}$ to $10^{-9} \mathrm{~m} / \mathrm{s}$, while PN2/PN3 
permeability is between $10^{-4}$ and $10^{-6} \mathrm{~m} / \mathrm{s}$. This could induce groundwater drainage at the interface between the substratum and the paleo-valley (Figure 2c). The model implies that the main paleo-valley imaged, feature B, is $1,000 \mathrm{~m}$ thick and drains large volumes of groundwater, as demonstrated by water inflows into the tunnel (up to 2,000 L/s; Maréchal et al. 2014).

The results obtained for Plaine des Fougères are summarized in a conceptual groundwater model presented in Figure 2c. The volcano slope includes three major structures considered as reservoirs with less permeable weathering profiles at the top. The semi-permeable substratum comprises old weathered formations from LM and/or PN1 volcanic periods. Because of a long quiescence period between PN1 and PN2, the substratum has been eroded, creating two large valleys. When the volcano activity resumed, both filled up with PN2 and PN3 products, and since then, they have drained groundwater through the Plaine des Fougères slope. The shallow part has been shaped by the most recent formations from PN4, supporting the emergence of limited aquifers. However, because of a decrease in geophysical resolution and without any geological information between the surface and the deep tunnel, the volcanic units within the substratum and the geometries of the buried valleys cannot be precisely characterized. Nevertheless, the location of springs and the occurrence of groundwater in the deep tunnel only below the paleo-valley tend to demonstrate that the geological structure induces stratified groundwater circulations within the critical zone of the Plaine des Fougères slope. The presence of three volcanic units creates groundwater stratification and significant drainage within both paleo-valleys. Since we interpreted the resistivity contrasts within volcanic units as a variation of weathering, we can assume that stratified groundwater circulations should occur in the fresh volcanic formations supported by the weathered aquitards from the older volcanic units, which could be saturated at the top. Nevertheless, only the location of springs at the interfaces between recent formations overlaying weathered lava flows confirm on the field our analysis (cf., Figures S3d and S3e as well as Figure S5b).

\section{Local to Regional Upscaling Approach}

The local study brought to light the presence of major buried valleys draining groundwater from rainy peaks to the coast. Such structures are well known for impacting groundwater circulation (Charlier et al., 2011; Lachassagne et al., 2014). In supporting information S4, we first analyzed the ability of the resistivity model to image the extension of such structures. Nevertheless, their limits and extensions remain unclear and cannot be mapped with simple depth/altitude resistivity slices. This is why we explored the potential of magnetic mapping. On the RTP map (Figure 3), the two major buried valleys of Plaine des Fougères are clearly delineated by positive anomalies (1; Figure 4). In line with 3D resistivity contrasts, both paleo-valleys cross the entire slope from the top to the coastal area (south-west to north-east). This radial orientation is specific to erosive structures, which emphasizes our interpretation about filled, buried valleys (Macdonald et al., 1983). Furthermore, similar patterns displayed on the RTP map (i.e., a positive anomaly oriented from the center to the external part of the volcano) may indicate the presence of buried valleys filled with PN2, PN3, and/or PN4 products.

Seven structures have been identified at the regional scale. Most of them consistent with geo-electrical structures similar to the Plaine des Palmistes (see supporting information S5). They mainly support groundwater flows, as evidenced by springs or highly productive aquifers partially known by local operators. All these elements have revealed hidden major buried valleys, which drain groundwater flows through several hydrological watersheds (Figure 3). As described in previous studies (Charlier et al., 2011; Vittecoq et al., 2014; Vittecoq et al., 2019), this certainly affects the estimation of water balance due to a concentration of groundwater resources at the bottom of buried valleys. A combined interpretation of electromagnetic and magnetic data sets makes it possible to delineate them in order to (a) implement groundwater watersheds in regional water balance estimations and (b) identify areas of interest for future groundwater studies.

\section{Conclusion}

In this study, we present a multiscale approach combining electromagnetic and magnetic data from airborne surveys in order to understand groundwater pathways through the critical zone. In previous hydrogeophysical studies in volcanic settings, resistivity imaging is confronted with wells or geological information 


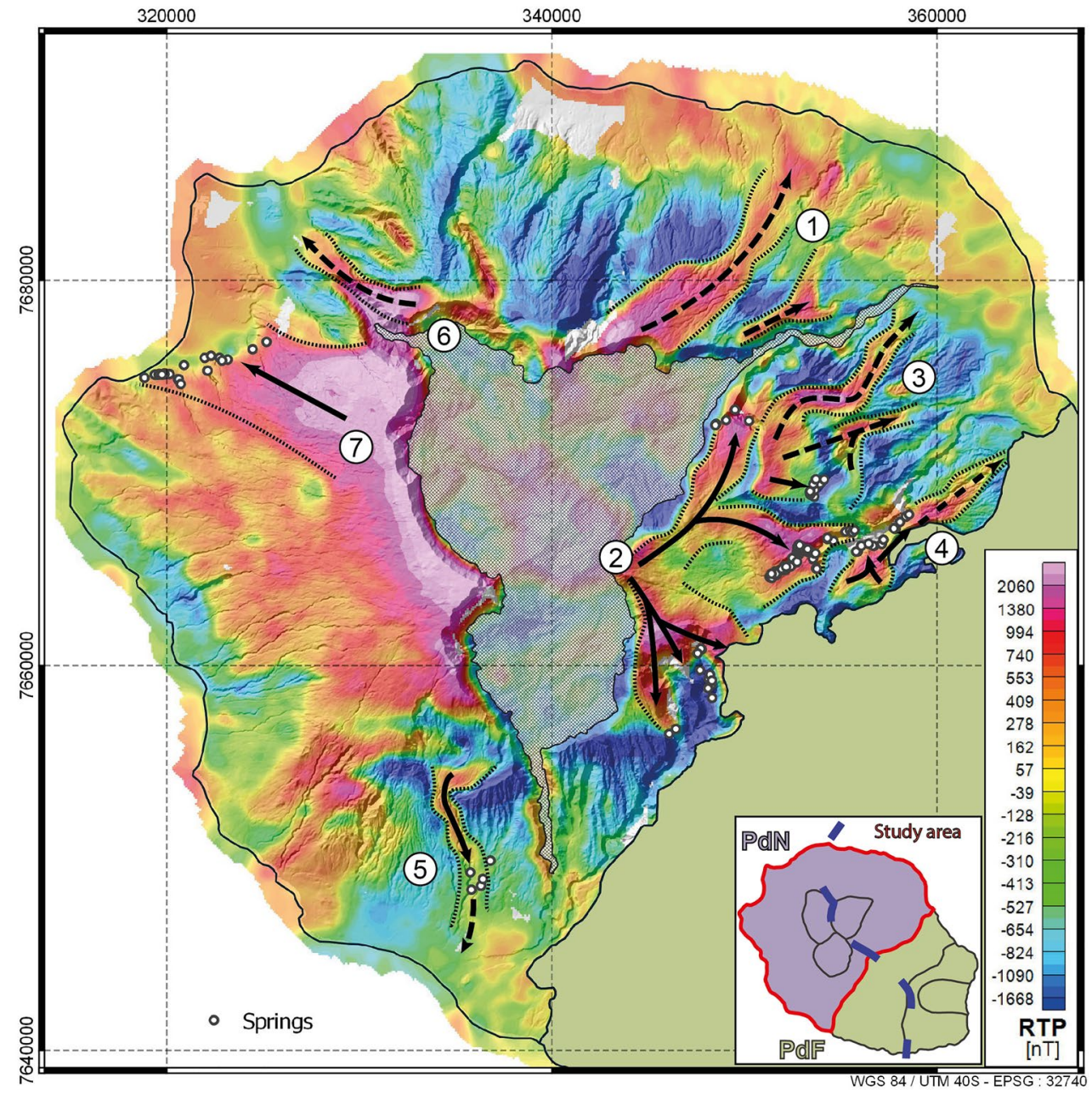

Figure 4. Magnetic signatures interpreted as buried valley patterns are delineated and numbered on the RTP map throughout the Piton des Neiges area. Seven hydrogeological structures are delineated by dashed lines: (1) Plaine des Fougères, (2) Bébour and Bélouve, (3) Massif de l'Est, (4) Ilet Patience and Massif cratère, (5) Les Makes, (6) St-Paul, and (7) Dos d'âne. Groundwater flow pathways appear as black arrows varying according to superficial evidence: (a) solid arrows when groundwater is drained to superficial springs and (b) dashed arrows where there is no superficial evidence. The inset represents La Réunion Island with both volcanoes-Piton des Neiges (PdN) and Piton de la Fournaise (PdF).

in order to define the resistivity threshold. Due to the geological heterogeneity of volcanoes, the representability of well logs is spatially bounded limiting the possibility of extrapolating AEM interpretations or requiring an extensive number of data and processing. Our approach tackles the interpretation of airborne geophysical data differently in order to extrapolate local results at large-scale. First, while resistivity imaging enables the determination of lithological geometries as well as saturation and/or clay content variations, the use of magnetic measurements allows for the identification of geological structures in the critical zone. Hydrogeological patterns are then deduced from limited geological and groundwater observations, and supported by geophysical signatures. The latter are then used to upscale hydrogeophysical interpretations.

In La Réunion, we defined a conceptual geological model delineating major structures at the local scale. We have shown that, in contrast to the general hydrological paradigm, old and slightly altered formations can be present in depths below weathering paleo-profiles. Compared with groundwater field data, it is possible to highlight a link between weathering paleo-profiles and the organization of groundwater pathways within the deep critical zone of shield volcanoes, which is rarely studied. Using volcanic units as the representative elementary volume, our approach does not allow for a detailed analysis of all the processes involved. Instead, the simplification of the groundwater behaviors allows us to extrapolate these results at the regional 
scale. The presence, extension, and orientation of seven major structures were thus defined over a $1,500 \mathrm{~km}^{2}$ volcano. Some known and previously studied structures made it possible to improve the validation of the conceptual model, while new unknown structures were revealed. These results will lead to improvements in groundwater management at both local and regional scales.

This hydrogeophysical study tackling both geophysical and groundwater issues presents several perspectives. Demonstrating the interest of a combined interpretation of airborne electromagnetic and magnetic data sets, we support the opinion that the joint inversion of both methods, rarely performed, would allow for the construction of robust and accurate models that reduce geophysical uncertainties. Our petrophysical sensitivity analysis as well as previous studies demonstrate the difficulty in distinguishing the influence of saturation and clay content on resistivity imaging. Extraction of the induced polarization signal from AEM data could herald new opportunities to improve hydrogeophysical interpretations. From a groundwater resource perspective, our study highlights the importance of deep circulations controlled by volcanic structures. Hence, the integration of such structures at the watershed scale will allow us to better estimate the recharge of coastal aquifers, the main resources in an insular volcanic context, and to define potential targets for water supply of inland populations.

\section{Data Availability Statement}

The airborne electromagnetic and magnetic data used in this research are presented in Martelet et al. (2014), while the treatments are detailed in Reninger, Martelet, Perrin, and Dumont (2019). Data availability is restricted by a free license due to data management policy required by government and national funders. In order to contract the free license and obtain the data, please contact the BRGM La Réunion team through their form at the bottom of their website: https://www.brgm.fr/en/regional-agency/reunion. Data sets for the petrophysical analysis are included in this paper: Archie (1942), Custodio (2004), Join, Coudray, and Longworth (1997), Soueid Ahmed et al. (2018), and Woudruff and Revil (2011).

Acknowledgments

This work as well as the SkyTEM survey in Réunion Island were supported by La Réunion local government, the European Union (through FEDER funding), the Office de l'Eau de La Réunion (Réunion Water Commission), and the BRGM. The authors are grateful to GRL editors, Andrew Parsekian and Carol Finn for their extensive and insightful reviews and comments, which significantly improved the manuscript.

\section{References}

Archie, G. E. (1942). The electrical resistivity log as an aid in determining some reservoir characteristics. Transactions of the AIME, 146(1), 54-62. https://doi.org/10.2118/942054-g

Auken, E., Christiansen, A. V., Westergaard, J. H., Kirkegaard, C., Foged, N., \& Viezzoli, A. (2009). An integrated processing scheme for high-resolution airborne electromagnetic surveys, the SkyTEM system. Exploration Geophysics, 40(2), 184-192. https://doi.org/10.1071/ EG08128

Aunay, B., Dewandel, B., Ladouche, B., Olivia, Z., \& Saussol, P. (2012). Identification des modalités d'exploitation des ressources en eaux souterraines du domaine d'altitude de l'Est de La Réunion-Phase 3 (secteur des Plaines) (Report, p. 166). BRGM. BRGM/RP-59245-FR. https://infoterre.brgm.fr/rapports/RP-59245-FR.pdf

Ball, L. B., Bedrosian, P. A., \& Minsley, B. J. (2020). High-resolution mapping of the freshwater-brine interface using deterministic and Bayesian inversion of airborne electromagnetic data at Paradox Valley, USA. Hydrogeology Journal, 28(3), 941-954. https://doi. org/10.1007/s10040-019-02102-z

Ball, L. B., Davis, T. A., Minsley, B. J., Gillespie, J. M., \& Landon, M. K. (2020). Probabilistic categorical groundwater salinity mapping from airborne electromagnetic data adjacent to California's Lost Hills and Belridge oil fields. Water Resources Research, 56(6), e2019WR026273. https://doi.org/10.1029/2019WR026273

Baranov, V. (1957). A new method for interpretation of aeromagnetic maps: Pseudo-gravimetric anomalies. Geophysics, 22(2), 359-382. https://doi.org/10.1190/1.1438369

Bénard, B., Famin, V., Agrinier, P., Aunay, B., Lebeau, G., Sanjuan, B., et al. (2019). Origin and fate of hydrothermal fluids at Piton des Neiges volcano (Réunion Island): A geochemical and isotopic (O, H, C, Sr, Li, Cl) study of thermal springs. Journal of Volcanology and Geothermal Research, 392, 106682. https://doi.org/10.1016/j.jvolgeores.2019.106682

Billard, G. (1974). Carte Géologique de la France, La Réunion. Quatre feuilles + notice (p. 40). BRGM. [Map].

Binley, A., Hubbard, S. S., Huisman, J. A., Revil, A., Robinson, D. A., Singha, K., \& Slater, L. D. (2015). The emergence of hydrogeophysics for improved understanding of subsurface processes over multiple scales. Water Resources Research, 51(6), 3837-3866. https://doi. org/10.1002/2015WR017016

Chandra, S., Auken, E., Maurya, P. K., Ahmed, S., \& Verma, S. K. (2019). Large scale mapping of fractures and groundwater pathways in crystalline hardrock by AEM. Scientific Reports, 9(1), 398. https://doi.org/10.1038/s41598-018-36153-1

Charlier, J.-B., Lachassagne, P., Ladouche, B., Cattan, P., Moussa, R., \& Voltz, M. (2011). Structure and hydrogeological functioning of an insular tropical humid andesitic volcanic watershed: A multi-disciplinary experimental approach. Journal of Hydrology, 398(3), 155-170. https://doi.org/10.1016/j.jhydrol.2010.10.006

Chauvin, A., Gillot, P.-Y., \& Bonhommet, N. (1991). Paleointensity of the Earth's magnetic field recorded by two Late Quaternary volcanic sequences at the Island of La Réunion (Indian Ocean). Journal of Geophysical Research: Solid Earth, 96(B2), 1981-2006. https://doi. org/10.1029/90JB02223

Custodio, E. (2004). Hydrogeology of volcanic rocks. In V. S. Kovalevsky, G. P. Kruseman, K. R. Rushton (Eds.), Groundwater studies: An international guide for hydrogeological investigations (Vol. 3, pp. 395-425). UNESCO. 
Custodio, E., Garcia, L. L., \& Amigo, E. (1988). Simulation par modèle mathématique de l'île volcanique de Ténériffe (Canaries, Espagne). Hydrogéologie, 2(1988), 153-167.

d'Ozouville, N., Auken, E., Sorensen, K., Violette, S., de Marsily, G., Deffontaines, B., \& Merlen, G. (2008). Extensive perched aquifer and structural implications revealed by 3D resistivity mapping in a Galapagos volcano. Earth and Planetary Science Letters, 269(3-4), 518-522. https://doi.org/10.1016/j.epsl.2008.03.011

Dumont, M., Peltier, A., Roblin, E., Reninger, P.-A., Barde-Cabusson, S., Finizola, A., \& Ferrazzini, V. (2019). Imagery of internal structure and destabilization features of active volcano by 3D high resolution airborne electromagnetism. Scientific Reports, 9(1), 1-11. https:// doi.org/10.1038/s41598-019-54415-4

Dumont, M., Reninger, P. A., Pryet, A., Martelet, G., Aunay, B., \& Join, J. L. (2018). Agglomerative hierarchical clustering of airborne electromagnetic data for multi-scale geological studies. Journal of Applied Geophysics, 157, 1-9. https://doi.org/10.1016/j.jappgeo.2018.06.020

Eggleton, R. A., Foudoulis, C., \& Varkevisser, D. (1987). Weathering of basalt: Changes in rock chemistry and mineralogy. Clays and Clay Minerals, 35(3), 161-169. https://doi.org/10.1346/ccmn.1987.0350301

Finn, C. A., Deszcz-Pan, M., Anderson, E. D., \& John, D. A. (2007). Three-dimensional geophysical mapping of rock alteration and water content at Mount Adams, Washington: Implications for lahar hazards. Journal of Geophysical Research: Solid Earth, 112(B10), B10204. https://doi.org/10.1029/2006JB004783

Finn, C. A., Deszcz-Pan, M., Ball, J. L., Bloss, B. J., \& Minsley, B. J. (2018). Three-dimensional geophysical mapping of shallow water saturated altered rocks at Mount Baker, Washington: Implications for slope stability. Journal of Volcanology and Geothermal Research, 357, 261-275. https://doi.org/10.1016/j.jvolgeores.2018.04.013

Foged, N., Marker, P. A., Christansen, A. V., Bauer-Gottwein, P., Jørgensen, F., Høyer, A.-S., \& Auken, E. (2014). Large scale 3-D modeling by integration of resistivity models and borehole data through inversion. Hydrology and Earth System Sciences Discussions, 11, 1461-1492. https://doi.org/10.5194/hessd-11-1461-2014

Gailler, L.-S., \& Lénat, J.-F. (2012). Internal architecture of La Réunion (Indian Ocean) inferred from geophysical data. Journal of Volcanology and Geothermal Research, 221-222, 83-98. https://doi.org/10.1016/j.jvolgeores.2012.01.015

Gayer, E., Michon, L., Louvat, P., \& Gaillardet, J. (2019). Storm-induced precipitation variability control of long-term erosion. Earth and Planetary Science Letters, 517, 61-70. https://doi.org/10.1016/j.epsl.2019.04.003

Gingerich, S. B., \& Voss, C. I. (2005). Three-dimensional variable-density flow simulation of a coastal aquifer in southern Oahu, Hawaii, USA. Hydrogeology Journal, 13(2), 436-450. https://doi.org/10.1007/s10040-004-0371-z

Herrera, C., \& Custodio, E. (2014). Groundwater flow in a relatively old oceanic volcanic island: The Betancuria area, Fuerteventura Island, Canary Islands, Spain. Science of The Total Environment, 496, 531-550. https://doi.org/10.1016/j.scitotenv.2014.07.063

Izquierdo, T. (2014). Conceptual hydrogeological model and aquifer system classification of a small volcanic island (La Gomera; Canary Islands). Catena, 114, 119-128. https://doi.org/10.1016/j.catena.2013.11.006

Join, J. L., Coudray, J., \& Longworth, K. (1997). Using principal components analysis and Na/Cl ratios to trace groundwater circulation in a volcanic island: The example of Reunion. Journal of Hydrology, 190(1-2), 1-18. https://doi.org/10.1016/S0022-1694(96)03070-3

Join, J.-L., Folio, J.-L., Bourhane, A., \& Comte, J.-C. (2016). Groundwater resources on active basaltic volcanoes: Conceptual models from La Réunion Island and Grande Comore. In P. Bachelery, J.-F. Lenat, A. D. Muro, L. Michon (Eds.), Active volcanoes of the southwest Indian Ocean (pp. 61-70). Springer Berlin Heidelberg. https://doi.org/10.1007/978-3-642-31395-0_5

Join, J. L., Folio, J. L., \& Robineau, B. (2005). Aquifers and groundwater within active shield volcanoes. Evolution of conceptual models in the Piton de la Fournaise volcano. Journal of Volcanology and Geothermal Research, 147(1-2), 187-201. https://doi.org/10.1016/j. jvolgeores.2005.03.013

Lachassagne, P., Aunay, B., Frissant, N., Guilbert, M., \& Malard, A. (2014). High-resolution conceptual hydrogeological model of complex basaltic volcanic islands: A Mayotte, Comoros, case study. Terra Nova, 26(4), 307-321. https://doi.org/10.1111/ter.12102

Lénat, J. F., Gibert-Malengreau, B., \& Galdéano, A. (2001). A new model for the evolution of the volcanic island of Réunion (Indian Ocean). Journal of Geophysical Research: Solid Earth, 106(B5), 8645-8663. https://doi.org/10.1029/2000JB900448

Ley-Cooper, A. Y., Brodie, R. C., \& Richardson, M. (2019). AusAEM: Australia's airborne electromagnetic continental-scale acquisition program. Exploration Geophysics, 51(1), 193-202. https://doi.org/10.1080/08123985.2019.1694393

Macdonald, G. A., Abbott, A. T., \& Peterson, F. L. (1983). Volcanoes in the sea: The geology of Hawaii. University of Hawaii Press.

Maréchal, J. C., Lanini, S., Aunay, B., \& Perrochet, P. (2014). Analytical solution for modeling discharge into a tunnel drilled in a heterogeneous unconfined aquifer. Groundwater, 52(4), 597-605. https://doi.org/10.1111/gwat.12087

Martelet, G., Reninger, P. A., Perrin, J., \& Deparis, J. (2014). Acquisition géophysique héliportée de l'île de La Réunion (Report, p. 91). BRGM. BRGM/RP-63818-FR. https://infoterre.brgm.fr/rapports/RP-63818-FR.pdf

Minsley, B. J., Abraham, J. D., Smith, B. D., Cannia, J. C., Voss, C. I., Jorgenson, M. T., et al. (2012). Airborne electromagnetic imaging of discontinuous permafrost. Geophysical Research Letters, 39(2). https://doi.org/10.1029/2011GL050079

Navarre-Sitchler, A., \& Brantley, S. (2007). Basalt weathering across scales. Earth and Planetary Science Letters, 261(1), 321-334. https:// doi.org/10.1016/j.epsl.2007.07.010

Oki, D. S., Souza, W. R., Bolke, E. L., \& Bauer, G. R. (1998). Numerical analysis of the hydrogeologic controls in a layered coastal aquifer system, Oahu, Hawaii, USA. Hydrogeology Journal, 6(2), 243-263. https://doi.org/10.1007/s100400050149

Parsekian, A. D., Singha, K., Minsley, B. J., Holbrook, W. S., \& Slater, L. (2015). Multiscale geophysical imaging of the critical zone. Reviews of Geophysics, 53(1), 1-26. https://doi.org/10.1002/2014RG000465

Peterson, D. E., Finn, C. A., \& Bedrosian, P. A. (2021). Airborne geophysical imaging of weak zones on Iliamna Volcano, Alaska: Implications for slope stability. Journal of Geophysical Research: Solid Earth, 126(3), e2020JB020807. https://doi.org/10.1029/2020JB020807

Peterson, F. L. (1972). Water development on tropical volcanic islands, type example: Hawaii. Groundwater, 10(5), 18-23. https://doi. $\operatorname{org} / 10.1111 / \mathrm{j} .1745-6584.1972 . t b 03586 . x$

Pryet, A., d'Ozouville, N., Violette, S., Deffontaines, B., \& Auken, E. (2012). Hydrogeological settings of a volcanic island (San Cristobal, Galapagos) from joint interpretation of airborne electromagnetics and geomorphological observations. Hydrology and Earth System Sciences, 16(12), 4571-4579. https://doi.org/10.5194/hess-16-4571-2012

Reninger, P.-A., Martelet, G., Perrin, J., Deparis, J., \& Chen, Y. (2016). Slopes of an airborne electromagnetic resistivity model interpolated jointly with borehole data for 3D geological modelling. Geophysical Prospecting, 65(4), 1085-1096. https://doi.org/10.1111/ 1365-2478.12465

Reninger, P.-A., Martelet, G., Perrin, J., \& Dumont, M. (2019). Processing methodology for regional AEM surveys and local implications. Exploration Geophysics, 51(1), 143-154. https://doi.org/10.1080/08123985.2019.1680249 
Salvany, T., Lahitte, P., Nativel, P., \& Gillot, P. Y. (2012). Geomorphic evolution of the Piton des Neiges volcano (Réunion Island, Indian Ocean): Competition between volcanic construction and erosion since 1.4 Ma. Geomorphology, 136(1), 132-147. https://doi org/10.1016/j.geomorph.2011.06.009

Sørensen, K. I., \& Auken, E. (2004). SkyTEM ? A new high-resolution helicopter transient electromagnetic system. Exploration Geophysics, 35(3), 194-202. https://doi.org/10.1071/EG04194

Soueid Ahmed, A., Revil, A., Byrdina, S., Coperey, A., Gailler, L., Grobbe, N., et al. (2018). 3D electrical conductivity tomography of volcanoes. Journal of Volcanology and Geothermal Research, 356, 243-263. https://doi.org/10.1016/j.jvolgeores.2018.03.017

Viezzoli, A., Christiansen, A. V., Auken, E., \& Sørensen, K. (2008). Quasi-3D modeling of airborne TEM data by spatially constrained inversion. Geophysics, 73(3), F105-F113. https://doi.org/10.1190/1.2895521

Vittecoq, B., Deparis, J., Violette, S., Jaouën, T., \& Lacquement, F. (2014). Influence of successive phases of volcanic construction and erosion on Mayotte Island's hydrogeological functioning as determined from a helicopter-borne resistivity survey correlated with borehole geological and permeability data. Journal of Hydrology, 509, 519-538. https://doi.org/10.1016/j.jhydrol.2013.11.062

Vittecoq, B., Reninger, P.-A., Lacquement, F., Martelet, G., \& Violette, S. (2019). Hydrogeological conceptual model of andesitic watersheds revealed by high-resolution heliborne geophysics. Hydrology and Earth System Sciences, 23(5), 2321-2338. https://doi.org/10.5194/ hess-23-2321-2019

Waxman, M. H., \& Smits, L. J. M. (1968). Electrical conductivities in oil-bearing shaly sands. Society of Petroleum Engineers Journal, 8(2), 107-122. https://doi.org/10.2118/1863-A

Woodruff, W. F., \& Revil, A. (2011). CEC-normalized clay-water sorption isotherm. Water Resources Research, 47(11). https://doi. org/10.1029/2011WR010919

\section{Reference From the Supporting Information}

Revil, A., Murugesu, M., Prasad, M., \& Le Breton, M. (2017). Alteration of volcanic rocks: A new non-intrusive indicator based on induced polarization measurements. Journal of Volcanology and Geothermal Research, 341, 351-362. https://doi.org/10.1016/j.jvolge 